\title{
Trees, KNeEs, AND Nurseries
}

When the Institute for Creation Research opened a new facility for its Museum of Creation and Earth History in Santee, California, in 1992, the exhibit that visitors saw before entering the gift shop featured two contrasting trees. The Creation Tree bore a variety of colorful "fruits." They represented "Genuine Christianity" and "Correct Practices," such as "true science," "true history," and "true government." The Evolutionary Tree offered more dangerous fare. From its branches hung "Harmful Philosophies" and "Evil Practices" that the ICR attributed to evolutionary thinking. At the top of the evil-practices list was promiscuity. Of the twelve items that followed, eight concerned sexuality, gender relations, or family life. They included pornography, abortion, homosexuality, and bestiality. "Communism" topped the list of harmful philosophies. Related items included humanism, atheism, amoralism, behaviorism, and materialism. Before arriving at the trees, visitors passed through the Hall of Scholars. On one wall of the corridor were proponents of evolution, who included familiar "social Darwinists" of the Right Andrew Carnegie and 
John D. Rockefeller Jr. At their center and placed higher in elevation than the rest was a portrait of Karl Marx. Visitors learned that "although he was a professing Christian in his youth, he became an atheist and (according to some) a Satanist in college."

For secular-minded Americans who were distressed by the public campaign against evolution in the 1970s and '80s, the ICR's linkage of evolution, communism, Marx, and Satan may have seemed bizarre. But to those who had been inspired by the writings of Henry Morris, Tim LaHaye, and other critics of evolution over the previous two decades, it would have made perfect sense. The attribution of a host of evils to evolutionary thought had become a staple of conservative Christianity. The prominence of sexual issues in this mix of "evils" was well established. In the period leading up to 1992, the language employed by antievolutionists focused less on "communism" or "socialism" and more on "secular humanism." This reflected the waning Cold War and the prominence of issues like abortion and homosexuality, on which the Stalinist Soviet Union was not in the forefront of progressive thought. By the end of 1991, the Soviet Union had disintegrated. But the focus on "secular humanism"

\section{Karl Marx (1818-1883)}

Karl Marx is considered to be the chief founder of

Communism. Although he was a professing Christian in his youth, he became an atheist and (according to some) a Satanist in college. His philosophies of history and economics were squarely based on evolutionism. In fact, he wanted to dedicate his book DAS KAPITAL to Charles Darwin, who had given him what he thought was the scientific foundation for Communism.

Figure 12. Karl Marx (1818-1883), museum display panel, 2012. Based on Henry Morris's writings, this display panel tightly connects Marx, Darwin, and (possibly) Satan at the Creation and Earth History Museum, Santee, California, established by Morris's Institute for Creation Research. Photo by author. Courtesy of Light and Life Foundation. 
represented a fundamental continuity, rather than a break, in Christian anticommunist thinking.

The evolution of evolutionary science in the 1970s also drew critical attention in ways that highlighted the red connection. As the public war over teaching evolution proceeded, one of the leading public defenders of evolution was Harvard paleontologist Stephen Jay Gould. Gould and his colleague Niles Eldredge diverged from the evolutionary mainstream with a set of ideas that they called "punctuated equilibrium," or "punk eek" for those in the know. As creationist critics observed and as Gould acknowledged, his idea of long periods of "stasis," interrupted by big sudden changes (on an evolutionary timescale), was roughly compatible with a Marxist view of history. Gould was also part of a group of left-wing evolutionary biologists who argued that the emerging sociobiological model of human behavior provided cover for racist and sexist ideas. Both these intramural scientific conflicts heightened the long-standing connection that creationists had made between Marxist politics and Darwinian science.

As Henry Morris and his cohorts in San Diego County built up their "creation science" infrastructure, they contributed to and were strengthened by a broader rise in Christian conservative activism, exemplified by the emergence of the Moral Majority in 1979. The election of Ronald Reagan in 1980 raised hopes that secular humanists could be defeated. As conservative evangelicals gained confidence that political efforts could make a difference, the prominence of "dominionist" ideas increased. Once associated with the relatively marginal R. J. Rushdoony, they now became more mainstream. D. James Kennedy, Jerry Falwell (a protégé of John R. Rice), Francis Schaeffer, Tim LaHaye, and others emphasized the importance of conservative Christians getting involved in electoral politics. The ICR collaborated with all of them in broadcasting its political message about the fruits of evolution.

Before taking independent organizational form, what became the ICR was the "creation science" division of the fledgling Christian Heritage College (CHC) in El Cajon, California. By 1978, CHC enrollment had grown to some five hundred students. Many came by way of LaHaye's Christian High School and through contact with the rapidly growing Scott Memorial Baptist. Others like Janet Laughton and Arthur Gutierrez came from 
the public schools. They had attended San Bernardino High School, met at $\mathrm{CHC}$, and were married at San Bernardino First Baptist soon after graduation. ${ }^{2}$ Early CHC instructors included Morris, Duane Gish, and a variety of others recruited based on their conservative theological credentials. ${ }^{3}$

Like all CHC students in their sophomore year, Laughton and Gutierrez would have taken six hours in "scientific creationism," taught in the early 1970s by Henry Morris himself. In the absence of textbooks written from Morris's young-earth perspective, Morris created handouts that developed into a series of texts, published by his in-house publishing arm, Creation-Life Publishers. These included Morris's own Scientific Creationism and The Troubled Waters of Evolution, as well as Duane Gish's Evolution? The Fossils Say NO! $!^{4}$ In the first few years of CHC, Morris had only two antievolution teaching counterparts: Gish, the Berkeley PhD who had worked with Morris in the CRS, and Harold Slusher, a longtime creationist professor of physics at the University of Texas-El Paso, who specialized in critiquing the validity of radiocarbon dating. ${ }^{5}$

As Morris has explained, using a genetics analogy, the ICR had a "hybrid origin." In 1970, a group of activists in the Los Angeles-based Bible Science Association (BSA) merged with the CHC creationists to form the Creation-Science Research Center (CSRC). The BSA group, led by Nell Segraves and her son Kelly, developed a strong interest in getting creationist textbooks into California public schools. The previous year the state board of education had approved the inclusion of creationism in the state's "Science Framework." Morris was sympathetic to the BSA group's goals, but over time, a rift developed. As Morris put it, he and Gish favored "educational and scientific means," whereas the Segraves group preferred "political and promotional efforts." In 1972, the CSRC split in two; the Segraves duo took with them the CSRC name, and Morris renamed his CHC-affiliated faction the Institute for Creation Research. ${ }^{6}$

As Morris and the ICR forged ahead through that first decade, they attracted a bevy of credentialed creationists to staff the growing number of classrooms in the hills of El Cajon. Richard N. Bliss became the ICR's director of curriculum development in 1976. With a master's in biology from the University of Wisconsin and a doctorate in science education from the University of Sarasota, Bliss had taught biology in Racine, Wisconsin, and then served as director of science education for the city's public schools. ${ }^{7}$ The inclusion of Bliss continued an upward trend. 
It strengthened Morris's claim that the ICR staff were carrying out legitimate scientific research. And it underlined the split with the Segraves group. The ICR, Morris seemed to be saying, would not dirty its hands in the rough-and-tumble world of politics.

And yet the output of the ICR in its first two decades undermines Morris's claim that he and his colleagues were not engaging in "political and promotional efforts." One example was the organization's monthly newsletter, Acts \& Facts, founded by Morris in 1972. Convinced that the publication's name was a gift from God, Morris recalled that it seemed to come to him from "out of the blue." ${ }^{8}$ Regardless of its ultimate source, the name did seem to neatly and cleverly convey the essence of scientific creationism. It harked back to the commonsense empiricism that animated his creationist geologist hero George McCready Price. In harmony with this vision of science, Morris continued to refer, in the decades ahead, to the basis of scientific creationism as "true facts." At the same time, the ICR used a presuppositional framework to talk about evolution. For the only facts that could be true were those produced by a God-governed mind.

The ICR communicated with its flock through Acts \& Facts. In comparison with the Creation Research Society Quarterly, which required subscribers to wade through obscure scientific terminology, Acts was friendlier to the average reader. More like a magazine than a journal, it was brief, on the order of eight pages; it was small, coming in at five by eight inches; it was in color; it featured photos, illustrations, and display ads. And it was free. ${ }^{9}$ By 1984, some seventy-five thousand people received Acts each month. According to an ICR survey, 90 percent of Acts readers were high school graduates; 73 percent had graduated from college; 35 percent had master's degrees; and 8 percent held doctorates. Contrary to liberal perceptions of creationists as ignorant yokels, ICR supporters were above average in their level of formal education. As for their occupational profile, the survey revealed the following: business, 21 percent; pastor, 19 percent; teacher, 18 percent; industry, 17 percent; homemaker, 7 percent; and student, 6 percent. ${ }^{10}$ Though the categories "business" and "industry" were vague, the results suggest that readers were above average in income.

Even as the ICR sought to reach a broader audience, the group could not ignore science. In presenting its presuppositional perspective on scientific 
topics, Acts sought to strike a balance between easily accessible material and more challenging fare. On the latter side of the spectrum was the June 1979 article by creationist astronomer Donald DeYoung. With a PhD in physics from Iowa State, DeYoung taught at Grace Seminary along with John C. Whitcomb Jr. and was serving as a visiting professor at CHC. His article appeared under the heading of the Acts \& Facts "Impact" series, which featured "Vital Articles on Science/Creation" and formed the centerpiece of each issue. "Defects in the Jupiter Effect" critiqued predictions by some scientists that a rare alignment of the planets would cause massive earthquakes on earth in 1982. Young adorned his article with a diagram of the expected planetary configuration and featured a table with the mass, tidal effect, distance from sun, and angle in degrees between planet and earth. Based on his calculations, Young rejected the Jupiter effect predictions (he was correct) and then drew broader antievolutionary conclusions for his readers. ${ }^{11}$

Articles of this ilk may have prompted the ICR to include in its 1984 survey a question to readers about the technical level of the "Impact" articles. Nearly half the respondents described the articles as "sometimes too technical." Only 9 percent thought they were "sometimes too simple." Fully 41 percent checked "other." Their written comments, according to Henry Morris, suggested they believed the articles were just fine. Nonetheless, based on the full survey results, Morris reported, the ICR might want to modify "Impact" for "greater ease of understanding." 12 Morris faced a twofold challenge. The ICR needed to popularize its coverage. Creationists, in this regard, were not different from evolutionists, going all the way back to Ludwig Katterfeld and his Evolution: A Journal of Nature during the 1920s. In a second respect, however, Morris and his cohorts faced a more daunting task. To bolster the claim that creationists were true scientists, they had to speak the language of science. And yet, as Morris and Whitcomb acknowledged in The Genesis Flood, the "importance of the question" hinged on politics.

Acts \& Facts made that clear in a number of ways. In 1977, "Impact" featured a series of pieces based on John Moore's articles from CRSQ demonstrating the impact of evolutionary thinking on the social sciences and humanities (and thus on impressionable young minds). In addition to informing readers about links between Darwin, Marx and Engels, and a variety of academics, Moore explained that Darwinism "sanctioned" a 
long line of twentieth-century dictators: Hitler, Mussolini, Lenin, Stalin, Khrushchev, "and current U.S.S.R. leaders as well." A chart in Moore's second article was titled "Relationships between Western Thought and Society and Marxist Communism and Totalitarianism." It revealed to readers the ineluctable connections between science, scientism, Western secularism, and Marxism. ${ }^{13}$ At the same time, the ICR also began to use the language of secular humanism, warning of the harmful effects on society of teaching evolution to young people. In a 1977 article on evolutionary humanism, Morris charged that such teachings had "generated an amoralistic attitude in society" with "devastating results." 14

Scientific creationists did not just publish articles; they took their show on the road. In January 1979, the ICR organized a creation conference in Coral Gables, Florida (their third held there), that stressed the "social impact" of evolution. Along the lines of Morris's repeated queries to readers seeking to establish the relevance of often seemingly obscure ideas, the official title for the conference was telling: "Evolution-What Difference Does It Make?” Speaking for the ICR, Richard Bliss delivered a keynote address to some seven hundred Miami students. Bliss's talk was titled "Have You Been Brainwashed?" echoing the language of the John Birch Society. He covered the ground laid by Moore's 1977 articles and emphasized the "harmful effects of evolutionary teaching on the minds of young people." More than two thousand people visited at least one conference session. Three local television stations and two radio stations covered the proceedings. ${ }^{15}$

The political nature of the Coral Gables conference stemmed not only from its ideological content but from the practical function it servedencouraging lobbying to change the public school curriculum. In 1980, Florida became just the latest state in which creationists sought to give "equal time" to creationism and evolution in the classroom. Until the US Supreme Court decision in Edwards v. Aguillard (1987) put a legal stop to this tactic, it seemed to hold promise. Reporting on Florida House Bill 107, Acts \& Facts proudly noted that the "seeds sown" in the successive creation conferences "are bearing fruit today." ${ }^{16}$ Even after Aguillard, the ICR continued to push along these lines and did not fail to mention the "social impact" of evolution. In 1988, when California adopted a set of evolutionary science standards, the ICR sent the state superintendent an "open letter," reprinted in Acts \& Facts, describing the dangerous 
effects of the "religion" of evolution. According to the ICR, evolution had spawned a series of "secular religions," which included "Atheism, Humanism, Communism, Nazism and Social Darwinism." 17 Despite Morris's break with the Segraves group, the ICR was clearly engaging in "political and promotional efforts."

Back at home in El Cajon, the ICR curriculum at Christian Heritage College ensured that students would learn about the deadly social and political consequences of evolutionary thinking. In 1974, Creation-Life Publishers brought out The Troubled Waters of Evolution, which Morris used at CHC. With a three-color cover portraying Darwin's Origin of Species sinking in a whirlpool of creationist truth, the book was an updated and expanded version of The Twilight of Evolution aimed at a broader audience. A brief introduction came from the pen of Tim LaHaye. He was identified neither as a founder of CHC nor as an owner of Creation-Life Publishers, but rather as president of Family Life Seminars, for which he was a minor celebrity in conservative Christian circles.

LaHaye's introduction says virtually nothing about the "scientific" content of Morris's book. Having little interest in or knowledge of the evolutionary literature, LaHaye singled out the social and political impact of evolution:

It is the platform from which socialism, communism, humanism, determinism, and one-worldism have been launched. All influential humanists are evolutionists, from Darwin to Huxley, Freud, and Pavlov to Rogers and Skinner. No one theory of man has ever influenced so many people. Accepting man as animal, its advocates endorse animalistic behavior such as free love, situation ethics, drugs, divorce, abortion. . . . It has devastated morals, destroyed man's hope for a better world, and contributed to the political enslavement of a billion or more people. ${ }^{18}$

LaHaye's précis of Morris's book accurately cataloged the range of evils attributed to evolution issuing from conservative Christians from William Bell Riley to Dan Gilbert to David Noebel. Summing up the value of Morris's new work, LaHaye boasted to readers that it "may well prove to be the most amazing book you have read in the last decade!" 19

After presenting a thumbnail history of creationism and an entropybased critique of evolutionary science, Morris got to the heart of the 
matter in a chapter called "Troubled Waters Everywhere." The trouble was that evolutionary concepts had infected all arenas of thought, from the physical and life sciences to the arts and humanities to Christianity itself. They also undergirded social and political practices such as racism (a topic of increasing attention from the ICR) and imperialism. A section on "Totalitarian Ideologies" examined Nazism and communism as products of Darwinian ideas of the "survival of the fittest." As anticommunists had done since the 1940s, Morris argued that rather than constituting opposing "right-wing" and "left-wing" political movements, they were "variants of the same species," namely, "evolutionistic, totalitarian collectivism." 20

Morris wove references to Marx and communism into other chapters in ways that elucidated for $\mathrm{CHC}$ students and others just how dangerous was the combination of atheistic, materialistic communism and Darwinism. Retelling the tale of how evolutionary ideas acquired their grip on humanity, Morris wrote about the nineteenth century in terms of conspiracy. All kinds of "revolutionary movements" were undermining respect for God, among them "Illuminist conspirators." Along with the Illuminati, wrote Morris, Marx and Nietzsche were "acquiring disciples-perhaps also financial backers, as student of conspiracies have frequently suggested." All these evil types were "evolutionists of one breed or another," Morris informed his readers. ${ }^{21}$

Bolstering Morris's later attempt to link Marx with Satan in the ICR creation museum, Troubled Waters gave detailed attention to the satanic origins of Darwinism. Morris began by observing that all "pagan" origin myths from the ancient world had a naturalistic focus. He traced them back to biblical Babel. As Carey Daniel had earlier argued in pinning race mixing on the devil, the central agent of the prince of darkness at Babel was King Nimrod. Morris knew all about Nimrod. As a freshman at Rice Institute in 1935, the budding creationist had penned a poem, "The Tower," in which "Babel's fools entwine their souls in humanistic schemes / In proud, utopian Nimrod-dreams." 22 Perhaps Morris was inspired by book 12 of John Milton's epic poem Paradise Lost, in which an unnamed Nimrod appears as a "mightie Hunter" who "from Rebellion shall derive his name." 23

Now writing as a mature creation scientist, Morris drew his evidence of satanic influence from the story of Babel in Genesis 10 and 11; 
descriptions of Lucifer in Isaiah, Revelation, and Ephesians; and admittedly inconclusive myths and archaeological fragments. Treating the potential involvement of Satan as a legitimate research question, Morris acknowledged that he could not be sure of his conclusion. Like all good scientists, he presented it in tentative fashion: "It therefore is a reasonable deduction, even though hardly capable of proof, that the entire monstrous complex was revealed to Nimrod at Babel by demonic influences, perhaps by Satan himself." 24

To bring home the ways in which evolution was "sociologically harmful," Morris contributed a final chapter with a Shakespeare-inspired title: "Boil and Bubble." Invoking the witches of Macbeth not only rhymed with the book's title. It conveyed Morris's allegation that evolutionists had turned the world from true Christianity to paganism. Morris's analysis of evolutionary approaches to population, ecology, racism, and, most of all, the "sexual revolution" showed that evolution was "false and deadly." It was a "corrupt tree" issuing "evil fruit." Those fruits were "materialism, collectivism, anarchism, atheism, and despair in death." Such trees, as Jesus had said, must be "hewn down and cast into the fire." 25 Thus did hundreds if not thousands of young Christian students learn the truth about evolution, ICR-style.

In between the publication of Troubled Waters and Morris's sequelEvolution in Turmoil-the field of evolutionary science was rocked by conflict over a new set of ideas known as "punctuated equilibrium" (PE). Developed by paleontologists Niles Eldredge and Stephen Jay Gould, PE presented a challenge to the reigning "modern synthesis" of evolution that had been consolidated in the 1940s. By shining a spotlight on this intrascientific battle, Morris sought to use one side's arguments against the other and thereby undermine the credibility of both. He quoted out of context and distorted Gould's ideas. The fact that Gould had become a genuine scientific celebrity-appearing on the cover of Newsweek in 1982-meant that such a strategy could pay real political dividends. ${ }^{26}$ Morris homed in on PE for a more specific political reason that was grounded in reality. In a chapter of Turmoil suggestively titled "Evolution and Revolution," he gave detailed attention to Gould's Marxist-oriented politics and how they informed his scientific ideas. ${ }^{27}$ In doing so, Morris updated the Red Dynamite tradition for the waning years of the Cold War. 
Given that Gould once wrote that his politics were a "private matter," one might think that his Marxism was a figment of Henry Morris's fevered creationist imagination. ${ }^{28}$ In its original incarnation, PE came without political baggage. Gould and Eldredge first published their ideas in an academic volume called Problems in Paleobiology (1972). They were grappling with a conundrum that had plagued evolutionary paleontologists since Darwin's time: the apparent "imperfection" of the fossil record. Trained in the modern evolutionary synthesis, they were convinced of the reality of natural selection and the existence of transitional species. But they also knew that in any given location, one could never find a complete sequence of finely graduated intermediate forms. While paleontologists tended to explain a "gappy" fossil record as an incomplete record of a fuller story, Gould and Eldredge argued that those gaps were a kind of positive evidence for how evolution took place. Following Ernst Mayr's idea of "allopatric" or geographic speciation, Gould and Eldredge focused on the migration of small subpopulations of a species ("peripheral isolates") to a new area where they branched off from the original parent species. Since new species developed in a different location, intermediate forms did not appear in the "core" area. But if the new species then spread back into that core area, the newly evolved variant would show up in the fossil record as distinctly different from the original species. Thus, concluded Gould and Eldredge, "Many breaks in the fossil record are real.” Rejecting "phyletic gradualism," in which whole populations of organisms evolved through a series of barely perceptible gradations, Gould and Eldredge argued for long periods of "stasis" or equilibrium, where little change occurred, "punctuated" by "rapid and episodic" speciation events. $^{29}$

In their early attempts to reorient paleontology along the PE axis, Gould and Eldredge only hinted at a broader philosophical or political agenda. In their first article, the authors nodded their heads to philosophers of science Paul Feyerabend and Thomas Kuhn: “The expectations of theory color perception to such a degree that new notions seldom arise from facts collected under the influence of old pictures of the world." 30 In Kuhnian terms, Gould and Eldredge were challenging the dominant "paradigm" of gradualism. But in a subsequent 1977 article that garnered wider attention (and provided the basis for one of Gould's popular columns in Natural History magazine), Gould and Eldredge made no bones 
about the political implications of PE. Calling for a rethinking of the entire field of biology, Gould and Eldredge claimed that biologists' preference for gradualism was not based on "objective study of nature" but rather a "metaphysical stance" determined by nineteenth-century European rulingclass politics. Facing threats from below, rulers championed the values of "order, harmony and continuity," which then found their way into the dominant models of science, including Darwinian biology. Noting that Karl Marx was a great admirer of Darwin, Gould and Eldredge quoted Marx on how Darwin had translated the social structure of English society into the natural world. Gould and Eldredge were not questioning the fundamentals of Darwinism. But they were suggesting that Darwin was a creature of his "cultural context." 31

From this vantage point, Gould and Eldredge observed that in other cultural contexts, such as the "socialist nations," a Marxist punctuational theory of change was the norm. That theory encompassed dialectical materialist laws drawn originally, in idealist form, from Hegel. One of these-the law of the transformation of quantity into quality-seemed particularly relevant to PE. To illustrate how this law applied to both society and nature, the authors quoted from the Soviet handbook of Marxism-Leninism: "The transition of a thing, through the accumulation of quantitative modifications, from one qualitative state to a different new state, is a leap in development. ... We often describe modern Darwinism as a theory of the evolution of the organic world, implying that this evolution covers both qualitative and quantitative changes. ... The evolutionary development of society is inevitably consumed by leap-like qualitative transformation, by revolutions." Consistent with their philosophical position, explained Gould and Eldredge, Soviet paleontologists had long supported a punctuational perspective. Closing out this section of the article, they offered one last example of the influence of politics on biology that would be quoted often by Gould's opponents: "It may also not be irrelevant to our personal preferences that one of us learned his Marxism, literally at his daddy's knee." 32

Though the authors did not specify which one received an early Marxist education, we know that it was Gould. ${ }^{33}$ The "daddy" on whose knee he sat in 1940s Queens was Leonard Gould. The son of eastern European Jewish immigrants, the elder Gould was a self-taught man who worked as a court stenographer and according to various accounts was "a passionate 
Marxist" who was "well-versed in Marxist theory." 34 Like Socialist Party evolutionary lecturer Arthur Lewis decades earlier, Leonard Gould combined a commitment to Marxist politics with a fanatical interest in natural history. The latter passion he bequeathed to his son through walks in city parks and visits to the American Museum of Natural History. Just what political inspiration the son derived from the father is unclear, but by young adulthood, Stephen Jay Gould was a left-leaning political activist. As a student in the early 1960s at Antioch College in Yellow Springs, Ohio, Gould joined the Students for a Democratic Society (SDS), the Student Peace Union, and the Congress of Racial Equality. He "threw himself" into the activities of these groups, including a series of sit-ins to racially integrate the local barbershop. ${ }^{35}$

As a young faculty member at Harvard in the late 1960s and early 1970s, Gould continued to join public protests, this time against the Vietnam War and police brutality. ${ }^{36} \mathrm{He}$ also became associated with a loosely organized group of left-wing, antiwar scientists called Scientists and Engineers for Social and Political Action, better known by the name SFP, after their semi-regular magazine, Science for the People. Early issues took up a wide range of subjects, from nerve gas to the Black Panther Party to "Birth Control in Amerika" to "Helping Science Education in Cuba and Vietnam."37

Henry Morris may not have known these details of Gould's political biography, but he knew that before promoting PE, Gould had emerged as a major voice for pro-evolutionism through his column in Natural History magazine. Morris also knew that in the mid-1970s, Gould became a major public critic of the new field of sociobiology and of its best-known proponent (and Harvard colleague of Gould's) Edward O. Wilson. ${ }^{38}$ In Sociobiology: The New Synthesis (1975), Wilson had summarized a body of field and theoretical work done originally on social insects such as ants and honeybees. Using the concept of kin selection, sociobiologists offered an evolutionary explanation for "altruistic" behavior that otherwise seemed to contradict the standard view of Darwinism as a bloody struggle for survival between individuals in a population. ${ }^{39}$

Wilson's efforts seemed reasonable enough, but for Gould and his likeminded colleagues in SFP's Sociobiology Study Group (SSG)—which included Harvard geneticist Richard Lewontin (1929-) — this new field had a dark side. Wilson implied that a number of human behaviors, including 
rigid sex roles, xenophobia, and genocide, might be best understood as the product of our genes. Gould and his SFP colleagues were alarmed. Wilson appeared to give credence to the idea that genes determined "the conduct of termite colonies" as much as they did "the social behavior of man." If racism, sexism, and war were genetic and not products of cultural evolution, then struggle against them was useless. Although Wilson espoused liberal politics, his sociobiology, in the eyes of Gould and the SSG, became "A Tool for Social Oppression." 40

Gould's colleague Richard Levins (1930-2016) was thinking along the same lines. A Harvard ecologist who began his career under Wilson's wing but soon joined Gould and Lewontin in their critique of sociobiology, Levins took an openly Marxist political stance. Like Gould, Levins learned Marxism at a young age. The "knee" in his case belonged to his grandfather, who read to Levins from a book by none other than "Bad Bishop" Brown, the maverick pro-evolutionist and Communist who came to prominence in the 1920s. Brown's Science and History for Girls and Boys (1932) was a favorite for parents and grandparents of "red diaper babies." ${ }^{41}$ As Levins recalled, "My grandfather believed that at a minimum every socialist worker should be familiar with cosmology, evolution, and history." 42 Unlike Gould, Levins joined the Communist Party of both the US and Puerto Rico (where he and his wife, activist Rosario Morales, lived for a time) and also spent years living in and promoting the cause of revolutionary Cuba. ${ }^{43}$ Levins and Lewontin collaborated closely and shared a Marxist outlook on science and society, reflected in their coauthored volume The Dialectical Biologist (1985). In a similar volume published some twenty years later, Levins and Lewontin claimed that their good friend and "comrade" Gould also identified himself as a "Marxist." 44

With few exceptions, Gould's public association with Marxism faded over time. In the summer of 1977, when Gould used his Natural History column to popularize the ideas of PE, he once again enlisted Engels, dialectics, and Soviet scientists, though without the lengthy quotation from the Stalinist manual (and any mention of his "daddy's knee"). In subsequent public discussion, Gould further distanced himself from that manual by describing it as "silly" and "propagandistic." Much later, he also distinguished between Marxism as a set of ideas-his "intellectual ontogeny"-and his "political beliefs," which, he insisted, were "very 
different from my father's." 45 When People magazine ran a two-page spread on Gould in 1986, focusing on his battle with both creationists and a rare stomach cancer, there was mention neither of his politics nor his father's. The article described PE as "heretical" but omitted its Marxist associations. When Gould departed this earth in 2002, the New York Times ran a long obituary. It said not a single word about his politics, Marxist or otherwise. ${ }^{46}$

Henry Morris, however, was onto something. Here, finally, was the fleshly embodiment of a claim that Morris had been making for decades-that evolutionism and Marxism were, as Gould himself later put it, "congenial." ${ }^{47}$ Sounding a bit like a Marxist himself, Morris, in Evolution in Turmoil, offered a materialist explanation for the rise of PE. It might not be "an accident of history," speculated Morris, that PE emerged during the 1970s, in the wake of the 1960s student protests. Its proponents were younger scientists (Gould was thirty-five in 1977) who had been in graduate school during that previous decade. They were less conservative than their scientific elders and less favorable toward "patriotism" and "western-style evolutionary capitalism." To them, Marxism sounded "noble" and "idealistic." Its proponents had acquired a foothold in the universities, despite "what may have been the excesses of McCarthyism." Under the influence of such people, struggles against racism and imperialism, wrote Morris, were "comingled" with "resistance to fighting Vietnamese Communism," resulting in "campus riots" and "street violence." Whether or not they were directly involved in these "riots"-Morris was not clear on this point-scientists like Gould came to see the existing gradualistic model of evolution as supporting the "establishment evils" they were combating. Thus they "devised" a new evolutionary "mechanism" and supported a "different political and social system" (socialism) that would accompany that new scientific explanation. ${ }^{48}$

Morris reminded readers that the evolution-communism connection had a long pedigree. As an atheist, Karl Marx was "a committed evolutionist" even before Darwin's Origin. He was so excited by Darwin's materialist scheme of natural history, wrote Morris, that Marx wanted to dedicate Das Kapital to him. Morris's basic point was correct, and the story about Marx and Darwin had been repeated by historians and others for years, including by Gould himself in a 1977 Natural History 
article. But by the publication of Turmoil in 1982, Morris could have known what historian Margaret Fay had established in 1978: it was not Marx who wrote to Darwin, but rather Marx's "son-in-law” Edward B. Aveling. He hoped to dedicate to Darwin The Student's Darwin, an edited collection of the master's writings. Darwin did, in fact, decline, knowing Aveling's association with atheism, materialism, and socialism. ${ }^{49}$

Morris also offered his readers a historical account of Marxist evolutionism in Soviet Russia. He correctly noted that many pro-evolutionists in the Soviet Union gravitated to a Lamarckian belief in the inheritance of acquired characteristics. The German-born Kammerer and the Russians Pavlov and Lysenko were attracted to Lamarckianism because it offered the possibility of rapid evolutionary change. Under Stalin, Morris explained, Lysenkoist evolutionism was even "imposed on Russian scientists as official state dogma." But ultimately failing the test of science, it was "falsified" and abandoned. In its place, Soviet scientists-and other Marxist evolutionists-sought out a theory of evolutionary change that was not slow and gradualistic. ${ }^{50}$

Even though Henry Morris abhorred Marx and Marxism, the ICR leader viewed Stephen Jay Gould and the newer generation of creationists as tactical allies. For a number of years, Morris had been tying the scourge of racism to Darwinism. Now came Gould and others who were willing to hold the evolution "establishment" responsible for its complicity. Not only did Gould criticize sociobiology on this score, but his Natural History articles covered figures in the evolutionary pantheon whose ideas were used to promote racial hierarchy. As quoted by Morris in Turmoil, Gould wrote of Haeckel's recapitulation theory that it "provided a convenient focus for the pervasive racism of white scientists." ${ }^{51}$ As Gould later noted, this description fit a number of eminent researchers whom Clarence Darrow had invited to provide expert testimony at the 1925 Scopes trial, including Henry Fairfield Osborn, then president of the American Museum of Natural History. ${ }^{52}$ Of course, Morris was silent on the long line of antievolutionists who were doctrinaire segregationists.

On evolution's "responsibility" for the "racist" Nazis and Fascists, Morris found less common ground with Gould. Morris explained that former left-wing student radicals like Gould had mixed feelings about Hitler. After all, Morris wrote, "Mussolini and Hitler did call their movements 'socialistic,' and the student movements of the 1960s bore many 
striking resemblances to the Hitler youth of the 1930s and early 1940s." ${ }^{53}$ As with his former melding of socialists and Nazis into a "totalitarian collectivism," Morris obscured the opposite political views held by the SDS and the Nazi Party. But his equation of student radicals, Nazis, evolution, and riots played into the long-standing equation of Darwinism with animalistic social disorder.

Having firmly linked Gould's political biography to Darwin and Marx, Morris treated the "revolutionary evolutionism" of PE. He quoted Gould and Eldredge from the 1977 Paleobiology article to show that they openly acknowledged their theory's "Marxist pedigree" and that it ran through Gould's own family. Morris also observed that Gould had "waffled" about whether or not he was a Marxist. Citing British Marxist and Darwin scholar Robert M. Young, who described Gould as a non-Marxist radical, Morris suggested that it might be advantageous for "doctrinaire" Marxists that Gould was not officially identified as one of their tribe, despite "whatever his actual beliefs might be." Gould might be a non-Marxist Darwinist Trojan horse concealing the true Marxist Darwinists inside. Morris's formulation gestured in the direction of an imaginary MarxistDarwinist conspiracy. But the suggestion gained credibility from Gould's lack of clarity about what being a "Marxist" meant to him. In any event, Morris concluded, PE had captured the hearts and minds of younger evolutionists who were fed up with the "capitalistic establishment." These scientific rebels were "seeking social justice and full egalitarianism not by slow evolutionary change but by rapid and even violent change if need be." ${ }^{54}$ Campus riots, indeed.

For all of the attention that Henry Morris lavished on Gould's Marxism in 1982, anticommunism was starting to lose its political punch. As Tim LaHaye predicted the following year, citing an obscure attorney as the source of his information, "The primary battle for the eighties and nineties will not be between Communism and anti-Communism or socialism and antisocialism, but between secular humanism and Christianity." LaHaye played a major role in fulfilling this prophecy about secular humanism. ${ }^{55}$ He drew inspiration from the combined work of two figures in the world of Christian conservatism-Francis A. Schaeffer IV (1912-1984), the quirky, world-famous evangelist, and John W. Whitehead (1946-), that obscure attorney and follower of R.J. Rushdoony who did the legal and 
historical brainwork that made "secular humanism" a viable new political target. That pair produced a vision of conservative Christian activism that spoke a new language but also represented a fundamental continuity with the Christian creationist anticommunism of previous decades. ${ }^{56}$

Hailing from Germantown, Pennsylvania, Francis Schaeffer began his pastoral career as a diehard fundamentalist and anticommunist. Studying with famed Presbyterian fundamentalists J. Gresham Machen and Cornelius Van Til and then briefly allying with ultra-separatist Carl McIntire, Schaeffer and his wife Edith traveled to Europe in 1955 to scout out possibilities for extending the reach of separatist fundamentalism. Soon souring on McIntire's approach, the Schaeffers opened up a Christian community called L'Abri Fellowship in their Swiss home. Situated on the way to a popular ski resort, L'Abri ("the shelter") by the mid-1960s had become famous as a pilgrimage site for evangelical travelers, curious hippies, celebrities, US soldiers stationed in Germany, and lost souls. Schaeffer was a big part of the attraction. Dressed in lederhosen and sporting long hair and a beard, Schaeffer could hold forth on a bewildering variety of topics, from ancient history to the latest trend in rock music. Unlike the old-style fundamentalists like John Rice and Carl McIntire, Schaeffer understood that he needed to meet young people where they were. He convinced many visitors that a Christian worldview was relevant and intellectually defensible. ${ }^{57}$

With his newfound fame, Schaeffer hit the American lecture circuit in the 1960s and published books that cemented his reputation as an original and thought-provoking Christian apologist. While Schaeffer never accepted the full "biblical law" program of Christian Reconstructionism, he did take from R.J. Rushdoony's writings the concept of America as a Christian nation. By the late 1970s, Schaeffer's activist son Francis Schaeffer V (better known as "Franky") persuaded his father to produce a series of films and companion books to spread his worldview to an even larger audience. Those included the panoramic, ten-part How Should We Then Live? The Rise and Decline of Western Thought and Culture (1976). In one episode, the elder Schaeffer, perched atop a pile of crushed cars in a junkyard, spoke to viewers about the devastating consequences for Western culture of evolutionary materialism. Evolution meant that all matter, including human beings, had arisen as a result of "chance." We were thus relegated to the status of "machines" that could be easily discarded. ${ }^{58}$ 
Whereas Francis Schaeffer had become an evangelical celebrity, John Whitehead was an unknown liberal, pot-smoking civil rights lawyer fresh out of law school in Fayetteville, Arkansas, when he found Jesus in 1974. Moving to California to join popular dispensationalist Hal Lindsay's church, Whitehead met R. J. Rushdoony and quickly came under his influence. By the mid-1960s, Rushdoony had begun providing expert testimony in court cases where Christian parents were prosecuted for failing to send their children to public or accredited private schools. In these early years of Christian homeschooling, Rushdoony was pivotal in formulating the necessary legal arguments, and in this effort Whitehead proved a valuable ally. Making use of Rushdoony's vast private library and his Christian publishing connections, Whitehead brought out The Separation Illusion: A Lawyer Examines the First Amendment (1977), his first work that aimed to break down the First Amendment barriers to creating a godly America. ${ }^{59}$ By that time, the US Supreme Court had issued a clear ruling, in Epperson v. Arkansas (1968), against the introduction of openly religious creationist teachings in the science curriculum. This was the ruling that Clarence Darrow had tried and failed to obtain more than forty years earlier as attorney for John Scopes.

Rather than trying to find a way to slip religion into a nonreligious curriculum, Whitehead now argued something completely different. In a 1978 law review article, he contended that the prevailing "secular" science curriculum was a form of "religion" to which courts were granting unconstitutional favor. ${ }^{60}$ Whitehead hung his argument on a little-noticed footnote in the 1961 Torcaso $v$. Watkins US Supreme Court decision that referred to secular humanism as a religion. ${ }^{61}$ The idea of an explicitly "secular" belief system as religious reinforced claims that R. J. Rushdoony had long been making-no thought was possible without God. ${ }^{62}$ From the Humanist Manifesto (1933) and the Humanist Manifesto II (1973), Whitehead gleaned a definition of the secular humanist faith. Secular humanism, according to Whitehead, "is a religion whose doctrine worships Man as the source of all knowledge and truth." Its most important "tenet" was the "absolutism of evolution." 63

Whitehead then proceeded to underline the dire practical effects of secular humanism, echoing decades of Red Dynamite political logic. Using an aggressive metaphor, Whitehead noted that evolutionary thinking had "penetrated" all arenas of life. By replacing absolute morality with relative 
morality, evolutionism had "altered the course of history." The result was "totalitarian regimes" such as Hitler and Mussolini; the "class struggles and atheistic posture" of communism; Freud's "sex-drive philosophy"; as well as racism and "unethical" capitalism. In Whitehead's own field of law, he lamented, evolution had created "sociological jurisprudence" in which the rules changed according to "experience." "The implications of this philosophy are frightening," wrote Whitehead, "when executed by someone with despotic power, such as a Hitler, a Stalin, or a Mussolini." Or as expressed by Russian historian and dissident Vadim Borisov, in yet another violent analogy quoted by Whitehead, Darwin, Marx, Nietzsche, and Freud provided the "humanist" theoretical basis for twentieth-century "totalitarianism, trampling the human personality and all its rights, rhinocerouslike [sic], under foot." ${ }^{64}$

By following the footnote in Torcaso to its logical legal conclusions, Whitehead had performed a real service for opponents of secular humanism. In 1980, this rising legal star on the Christian Right received an unexpected call from Franky Schaeffer. Schaeffer senior and Whitehead were soon working closely together on a book that would make the sage of L'Abri even more famous and sought-after by conservative Christians: A Christian Manifesto (1981). Just as Whitehead had sought to reorient his readers to the dangers secular humanism posed to their constitutional freedoms, Schaeffer also aimed to "connect the dots" in a new way. The problem, as he told readers, was that Christians had been viewing things in "bits and pieces" rather than in "totals." They had failed to see that the moral decline of society was the product of not just a list of specific policies, but an entire "world view." ${ }^{65}$ Like Whitehead, Schaeffer made evolution the central component of secular humanism, but repeatedly referred to it, in his idiosyncratic way, as the "material-energy, chance concept of reality." Consonant with his charge that human beings were treated as "machines," Schaeffer used the language of physics, rather than biology. Secular humanists, that is, viewed human beings "as a complex arrangement of molecules." But they also viewed "Man" as "an intrinsically competitive animal." ${ }^{66}$

As much as Schaeffer helped to shift the discourse of Christian conservatism away from the fanatical anticommunism of his former colleague Carl McIntire, the traces of that tradition were evident. In How Should We Then Live? Schaeffer spent several pages portraying the repression 
and relative humanist morality of Marxist communism as a "gigantic contrast" to the absolute God-based morality and freedom produced by the Protestant Reformation. ${ }^{67}$ This theme reappeared in A Christian Manifesto. At the center of the page following the preface were three lines of text, one stacked on top of the other: "The Communist Manifesto 1848," then, "Humanist Manifesto I 1933," and finally, "Humanist Manifesto II 1973." "68 Humanism was a genealogical descendant of communism. Even Schaeffer's first invocation of those who promoted the "material-energy chance" worldview qualified it by adding, "whether they are Marxist or non-Marxist." 69 The specter of anticommunism thoroughly haunted the new edifice of anti-secular humanism.

If Whitehead and Schaeffer succeeded in laying down the legal and intellectual framework for confronting the forces of secular humanism, the task of popularizing that framework fell to Tim LaHaye. By the late 1970s, LaHaye had gained a wide audience in the Golden State for his distinctive mix of conservative Christian counseling, anticommunist activism, jeremiads on the decline of American morality, and Bible prophecy. In 1979 he took a step more directly into politics by helping to form Californians for Biblical Morality (CBM). LaHaye's group channeled a conservative backlash to the California gay rights movement. In the previous year, gay rights activists and their allies had defeated Proposition 6, which would have made it legal to deny employment to teachers based on their sexual orientation. In response, CBM members rallied and signed petitions in support of politicians who opposed gay rights, supported capital punishment, and called for the return of prayer in the public schools. They sought, as LaHaye described it, to "halt the juggernaut of amoral humanism in our state." They were joined by a number of allies from outside California, including a charismatic preacher from Lynchburg, Virginia, by the name of Jerry Falwell. CBM provided a model for the formation of Moral Majority Inc. later that year. ${ }^{70}$

The centerpieces of LaHaye's effort to publicize the dangers of secular humanism were The Battle for the Mind (1980) and The Battle for the Public Schools (1983). In both, LaHaye tipped his hat to Whitehead. The 1980 volume came out a year before Schaeffer's A Christian Manifesto, but LaHaye had been reading Schaeffer, and he dedicated Battle for the Mind to that "renowned philosopher-prophet of the twentieth century."71 
LaHaye's dystopian vision suggests that the campaign against secular humanism did not break from the anticommunist tradition but adapted it to new circumstances. ${ }^{72}$

As LaHaye told the story, a secular humanist conspiracy was afoot in the land. Christians faced "an invisible enemy." Its name was "humanism," and its "target" was "your mind." The conspirators had "quietly woven" alarming changes into the social fabric. The public schools had fostered "hostility" to morality, religion, creationism, and "moral" sex education. As America marched toward "Sodom and Gomorrah," LaHaye offered both a "shocking, detailed exposé of this regression and a "practical handbook" for fighting back. ${ }^{73}$ The final section of the book told readers how they could wage that fight. It included a questionnaire for political candidates to determine their positions on "morals"; a "Key 16" prayer list of the federal, state, and local officials a Christian voter had a hand in choosing and might pray for; a pitch for Moral Majority Inc.; and a list of practical political tips. ${ }^{74}$

Where Francis Schaeffer had made ample use of film to spread his message to the Christian masses, LaHaye used schematic graphics that conveyed the contrasting tenets of the humanist and Christian worldviews. Employing Schaeffer's metaphor of a Christian "base," LaHaye placed the personified rival worldviews (both apparently male) on a three-level platform, which sat atop a row of books. The Christian figure, wearing a large letter $S$ for "servant," was perched upon the foundation stones of God, Creation, and Morality. Foundational reading material was labeled "Law," "History," and a variety of books from the Old and New Testaments. A globe, adorned with a cross and labeled "Compassionate World View," hovered above. The Humanist, whose upraised arms rendered his bodily form into the shape of the letter $H$, stood upon Amorality, Evolution, and Atheism (tenets one through three). His globe read "Socialist One World View" (tenet four). His reading list featured early Greek materialists, Enlightenment thinkers (including Illuminati founder Adam Weishaupt), skeptics, and modern philosophers. He wore what looked like a lowercase $s$ imprisoned inside a larger $A$, which presumably stood for "autonomous man" (tenet five). ${ }^{75}$

Just as Francis Schaeffer called Christians' attention to "totals" and sought to awaken them from their slumber, LaHaye warned that humanists had cleverly "duped" many Americans into innocently accepting the 
tenets of what he termed "the world's greatest evil." By drawing heavily from the writings of socialist and humanist Corliss Lamont as well as Lamont's old friend Julian Huxley, LaHaye aimed to open the eyes of duped Christianity. Humanists were atheists; believed in evolution; viewed morality as subject to change ("amorality"); thought that human beings were essentially good and capable of solving their own problems without God's help ("autonomous man"); and were inclined to favor world government and to disfavor "Americanism, capitalism, and free enterprise." LaHaye not only cited humanists' leadership of UNESCO and UNICEF but pointed to Lamont's favorable comments on the Marxist philosophy of dialectical materialism. Evolution provided the foundation for all these tenets, and LaHaye quoted Whitehead and John Conlan on evolution "shifting the base" from absolute morality to arbitrary absolutes. $^{76}$

All five tenets of humanism were meant to shock LaHaye's readers into action, but perhaps none more than evolution-inspired sexual "amorality." "If you believe that man is an animal," he wrote, "you will naturally expect him to live like one." This was an old weapon in the arsenal of antievolutionism, but LaHaye tied it to new manifestations of sexual social change: easy divorce, abortion "on-demand," sex education "forcibly taught" to schoolchildren, coed college dormitories, homosexuality as "an optional life-style," easy access to pornography, and, to boot, the availability of marijuana and "hard drugs." No matter whether one called it "permissiveness" or "free love," LaHaye wrote, these were just code words for "adultery, fornication, perversion, abomination, and just plain sin."77 Raising the stakes even higher in his subsequent volume, The Battle for the Public Schools: Humanism's Threat to Our Children (1983), LaHaye focused in on the effects of this moral sea change on the nation's youth. The threat posed by humanist sex education encompassed five chapters, starting with "How to Make Sexual Animals Out of a Generation of Children." 78

In case his picture of "amorality" in Battle for the Mind was not sufficiently alarming, LaHaye wrapped up his survey of humanist evil with a nightmare scenario reminiscent of the Bolshevik Bureau of Free Love. Humanists were plotting to merge America with Communist countries and "third-world dictatorships" into a "one-world socialist state." An elite humanist "ruling class," supported by a military, would rule over 
the "masses." Children would be "wards of the state." Men and women would do "the same work." And given humanist "amorality," the masses, both young and old, would apparently be encouraged to engage in promiscuous sex and prostitution, "practice" homosexuality, obtain abortions at will, read pornography, and use drugs. All of this, the humanists hoped, would come to pass by the year $2000 .{ }^{79}$

LaHaye's updated conspiratorial viewpoint had roots stretching back to William Bell Riley of the Protocols of the Elders of Zion. This continuity is evident in The Battle for the Public Schools where LaHaye confronted detractors who found his claims "bizarre." ${ }^{80}$ Most educators, LaHaye acknowledged, "scorn the conspiracy theory." But "many people," he writes, believe that the conspiracy is real and involves the Illuminati, the Rockefeller-funded Council on Foreign Relations, and Trilateral Commission. Riley had argued that even if the Protocols were a forgery, they still accurately foretold world events. LaHaye insisted that he "did not know" whether or not the humanist conspiracy theory was valid. But it might explain why, for example, the evolutionist and humanist John Dewey was a "committed world socialist" and why he spent three years in the young Bolshevik republic. Whether he then worked for the "socialists or Marxists" in America "would be difficult to prove," LaHaye admitted. But then again, he asked, would the outcomes-progressive education and the erosion of moral absolutes-have been any different? ${ }^{81}$ Whether or not there was an actual communist/humanist conspiracy going back centuries to the Illuminati, assuming that it existed made good practical sense for conservative Christians.

Battle for the Mind was a Christian best seller. By July 1981, Revell had printed 375,000 copies. The term "secular humanism" emerged from obscurity to become common currency in conservative Christian circles. As one study noted, "by the end of 1980, nearly all had adopted it as their enemy." A letter to the Charlotte Observer that year reflected the rich mix of ingredients that LaHaye had identified: "abortion, pornography, evolution, sex and values education, socialism, communism, and bureaucratic government are all part of secular humanism." 82 The success of Battle testified to LaHaye's ability to make Schaeffer's more historical and theoretical discussion relevant to the masses. But LaHaye also had good timing. As indicated by blurbs on the book's back cover-written by Jerry Falwell (1933-2007) and D. James Kennedy (1930-2007)—LaHaye wrote not as 
a lone individual but as part of an organized and growing movement that aimed to put a "moral majority" back in charge of America.

As the founder and central spokesman for the Moral Majority, Rev. Jerry Falwell Sr. has gone down in history as the man who made the New Christian Right a potent political force in late twentieth-century America. Less appreciated is the Red Dynamite political genealogy that enabled Falwell to draw inspiration from both J. Frank Norris and John R. Rice. Growing up in Lynchburg, Virginia, Falwell accepted Jesus into his life at the age of nineteen at the Park Avenue Baptist Church in 1952. Park Baptist was one of a small but growing number of churches that chose to affiliate with the Bible Baptist Fellowship (BBF), led by G. Beauchamp Vick, the former right-hand man of J. Frank Norris. ${ }^{83}$ Attending Lynchburg's Brookville High School, Falwell had dreams of attending Notre Dame or Virginia Tech to study mechanical engineering-he was both a star athlete and class valedictorian. But with his conversion at Park Avenue, he decided to devote his life to God. When Falwell asked his pastors where he should continue his schooling, they directed him, consistent with his church's independent fundamentalist affiliation, to study with Vick at Baptist Bible College in Springfield, Missouri. If Falwell had gone to nearby Virginia Tech instead, he would have met professor of civil engineering and devout Baptist Henry Morris. But they would soon cross paths. After Morris started up his own non-SBC-affiliated Baptist church in Blacksburg in 1962 he invited Falwell to guest preach there. ${ }^{84}$

By the early 1960s, Falwell was pastoring the growing BBF-affiliated Thomas Road Baptist Church back in Lynchburg, which he had launched in 1956. He combined an orthodox fundamentalist Baptist message with the new technologies of radio and television and a vigorous door-knocking campaign. Falwell rapidly attracted new congregants. His televised Old Time Gospel Hour show was consciously modeled on Baptist fundamentalist preacher Robert C. Fuller's Old Fashioned Revival Hour radio show, which had mesmerized Falwell as a youngster. ${ }^{85}$ Falwell preached a typical Southern Baptist fundamentalist message that revolved around the inerrancy of scripture, the sinfulness of worldly pleasures, the dangers of communism, and the virtues of racial segregation. ${ }^{86}$ But he possessed an atypical zeal for building what became one of the first "mega-churches" in the nation. In 1963, the Thomas Road Baptist Church spawned a 
summer camp for kids (which Henry Morris's children attended), and shortly thereafter a prison program, a Christian school, and Lynchburg Bible College, soon to be Liberty Baptist College and then Liberty University. By the early seventies, Falwell's weekly congregation numbered nearly seven thousand. He reached millions more through the airwaves. And he was now Dr. Jerry Falwell, thanks to an honorary doctoral degree from Lee Roberson's fundamentalist Tennessee Temple University in Chattanooga. ${ }^{87}$

Given Falwell's independent Baptist fundamentalism, his zeal for moral, upright living, and his Norrisite-breakaway heritage, it was almost foreordained that his fate would mix with that of John R. Rice. When Falwell began preaching in Lynchburg, he took out a subscription to Sword of the Lord and met Rice soon thereafter. Over the course of the decades, Rice gave Falwell prominent attention in his newspaper. By the late 1970s, Rice viewed the Lynchburg preacher as his protégé and potential successor. In 1971, Rice added Falwell to the Sword "Cooperating Board" and invited him to preach at Sword conferences. In 1975, Rice paid tribute to Falwell, "our beloved friend," whom "God is wonderfully blessing." Rice ran ads in Sword for Falwell's pastoral conferences and for Liberty College. ${ }^{88}$ In 1976, Rice even commissioned The Grim Reaper, a "Christploitation" film by Nashville-based filmmaker Ron Ormond, in which Falwell portrayed a preacher hammering away at the point that Satan, his demons, and hell are all real. ${ }^{89}$ Most importantly, Rice published Falwell's words. Between 1974 and 1979, Falwell's sermons, always accompanied by his photo, appeared on the front page of Sword of the Lord twelve times. ${ }^{90}$

Falwell's primary theme was winning souls for Jesus. But he consistently wove into his sermons a concern about the moral "permissiveness" of America, the ongoing dangers of communism, and the obligations of preachers to meet all these issues head-on. As he related in a 1979 sermon reprinted in Sword, when a talk show host questioned whether it was appropriate for a preacher to address political issues, Falwell responded by saying that "homosexuality, abortion, pornography are not political issues, they are moral issues that have become political." 91 Falwell rarely addressed evolution explicitly in this period. But in a 1978 sermon on abortion, Falwell did highlight the "evolutionary explanation" as the culprit since it taught Americans that we were descended 
from animals. "Americans are aborting birth," he charged, "as if the child is an unnecessary animal." 92

Despite his relative silence on evolution in the 1970s, Falwell had the opportunity to be educated on the subject by his regular reading of Sword. Rice reran older pieces that sought to show that evolution was "only" a theory and therefore amounted to a pseudoscientific "hoax." He printed articles showing that evolutionary claims contradicted the Bible, including his own "God's Perfect Creation in Six Literal Days." Most relevant for Falwell's future trajectory, Rice featured commentary that placed evolution in the lens of moral decline as yielding evil "fruits." These included a front-page reprint of Rice's 1954 sermon "Dangerous Triplets" (renamed “Our Triple Enemies”). More accessible for Falwell's generation was a new sermon by Rice on the moral decline of American public education. The schools, Rice revealed, were run by "infidels" who believed in "godless evolution," that man is only an "animal," and that therefore there are "no absolute rights and wrongs." Instead, students get "free sex without marriage," disrespect for the American flag and American heroes, and "filthy, dirty" books like Catcher in the Rye. Evolution was the basis of the "humanistic philosophy" of John Dewey, which had brought about this educational nightmare. It was the basis, too, "of Russian communism."93

Regardless of what Falwell absorbed from Rice on the subject of evolution, we know that Rice meant a great deal to him. Speaking at the Sword editor's funeral in late 1980, Falwell said that Rice was "God's man for the hour. I looked on him as the guardian of fundamentalist truth for this generation." Later that day, Falwell confided a more personal appreciation to Rice's grandson Andrew Himes. "I must tell you that John R. Rice was a father to me," said Falwell. He was, Falwell told Himes, "my mentor, my teacher, my friend, and my prayer partner."94 As Falwell assumed the mantle of "God's man" for a new age, he owed much to the example and teachings of John R. Rice.

What Falwell did not say is just how indebted he was to Rice for a tangible asset that helped to launch Moral Majority Inc. As Falwell's Liberty Baptist College associate Elmer Towns recalled, the two of them visited Rice in Murfreesboro, Tennessee, in the summer of 1979 as talks about forming the Moral Majority were proceeding. Falwell understood that even if he and Rice shared a similar political and theological outlook, the old man had no interest in forming an explicitly political organization. 
With the explanation that they sought to double the enrollment at Liberty Baptist, Falwell asked to borrow something that could reach untold numbers of just the right people: the Sword of the Lord mailing list. Rice readily agreed. They left town with the names of two hundred thousand Baptist ministers. As Elmer Towns recalled, "that was magic." 95 Just as William Bell Riley passed the torch to Billy Graham in Minneapolis in 1947, so did John R. Rice become a living link, in more ways than he knew, between the Old and New Christian Right.

And yet, like Henry Morris, who minimized the importance of George McCready Price to his own thinking, Falwell was ambivalent about Rice's legacy. In a 1982 issue of the Liberty Baptist College-sponsored Fundamentalist Journal, editor Falwell ran a tribute to John R. Rice. It accurately described Rice as an enemy of "atheism, evolution, modernism, and worldliness." On the other hand, it omitted Rice's anticommunism. And it said nothing about Rice's uncompromising segregationism and opposition to interracial marriage, which he carried to his grave. Already by the early 1970s, Rice was isolated on these issues even among fundamentalists. ${ }^{96}$ In response to his continuing opposition to interracial marriage and defense of segregation, Rice received a string of letters from critics, both Black and white, who canceled their Sword subscriptions and scored Rice's racism. In 1970, when Rice defended the refusal of Bob Jones University to admit Black students, a self-described "black fundamentalist" wrote Rice from Chicago to say that "Your position is not moral, biblical, Christian or even truly American." Rice replied by calling the man "wholly racist." Falwell had been as pro-segregationist as any Southern Baptist, but by the 1980s he had decisively changed his tune. ${ }^{98}$ As Elmer Towns commented, "John R. Rice was to the right of Jerry." 999 The evolution of Falwell's views probably helps explain a remarkable fact. In Falwell's best-selling autobiography of more than four hundred pages published in 1987, the man who was like a "father" to Falwell is nowhere to be found. ${ }^{100}$

As John R. Rice might have expected, the Moral Majority Inc., Falwell's Liberty Baptist College, and Falwell's own televised sermons played important roles in promoting creationist politics in the 1980s. Falwell's various roles often overlapped. A case in point was a "paid ad" from Falwell's Old Time Gospel Hour (OTGH) that appeared in the April 20, 1981, issue of the monthly Moral Majority Report. In response to the ACLU-backed court challenge to the "balanced-treatment" law in 
Arkansas (which would be struck down in federal court the following year in McLean v. Arkansas), Falwell asked readers to "Cast Your Vote" on the "Creation or Evolution" "ballot." He could be fairly sure that his readers-many of whom were longtime subscribers to Sword of the Lord-would vote "NO" to the question, "Do you agree that public school teachers should be permitted to teach our children as fact that they descended from APES?" In return for sending in their ballots, readers were offered free copies of The Remarkable Birth of Planet Earth (1972). Moral Majority members might have been forgiven for assuming that Falwell was the book's author, but the tiny, blurred type obscured the name of Henry Morris. ${ }^{101}$

One of the first productions of the ICR's Creation-Life Publishers, Remarkable Birth was designed to reach beyond the world of "scientific creationism." Even the title-alluding to Hal Lindsay's apocalyptic best-seller The Late, Great Planet Earth (1970)-bespoke those marketing ambitions. ${ }^{102}$ Coming in at only ninety-five pages with a three-color cover, this pocket-size paperback was aimed, Morris wrote in his preface, at "busy, but interested readers." Like Twilight, Troubled Waters, and Turmoil, the book recast arguments from The Genesis Flood. But in this volume that Falwell offered to his readers, Morris got right to the political point. In the opening sentence of the preface's second paragraph, he explained why readers should keep on reading: "evolution . . . is largely responsible for our present-day social, political, and moral problems." 103 Morris quoted Jesus on evil fruit and then got more specific about the results of the "root" of evolution. The list included all the usual suspects: "atheism, communism, nazism, behaviorism, racism, economic imperialism, militarism, libertinism, [and] anarchism." If readers of the Moral Majority Report had any lingering doubts about whether evolution had to be opposed, Falwell hoped to scotch them with the words of the man whom the back cover of the book identified as "one of America's greatest authorities on scientific creationism."104

Which is not to say that Falwell was trying to hide his collaboration with the ICR. The creationist biology department at Liberty Baptist College was headed by Dr. Lane Lester (1938-). With a PhD in genetics from Purdue, Lester had until recently served the ICR as research associate in biology, taught at Christian Heritage College, and was a regular speaker at ICR summer institutes. Lester penned articles for the Moral Majority 
Report that urged teachers to order ICR materials for their classrooms, insisting that they were "completely scientific with no reference to the Bible.” ICR speakers ran workshops in the West, explained Lester, while Liberty Baptist College would provide that service for the eastern half of the country. ${ }^{105}$ In 1978, the ICR's Duane Gish, who had recruited Lester to creationism, and Morris himself had spoken at Falwell's church in Lynchburg. ${ }^{106}$

The political and moral concerns that underlay Liberty Baptist College's biology curriculum surfaced in the mandatory "History of Life" course taught by assistant professor of natural science James L. Hall. ${ }^{107}$ While the bulk of the course material concerned problems with the "evidences" of evolution, the class began with a meaty section on the "History of Human Thought." Based implicitly on Francis Schaeffer's framework from How Should We Then Live? Hall's history traced the development of a non-God-based "worldview" starting with the Renaissance and ending with modern-day "Atheistic evolutionary Humanism." Once again reflecting Richard Weaver's "ideas have consequences," the course outline indicated that "Inner Thought world determines outward action." In the modern period, the "flood tide of humanism" had produced Nazism, the "hippie world of the 1960's," the widespread use of hallucinogenic drugs and rock music, and the horrors of the French and Russian Revolutions. The former was reduced in meaning to "Napoleon Authoritarian rule." The latter was summed up in three words: "Lenin-BloodbathCommunism." 108 That summary neatly encapsulated the decades of Christian fundamentalist and antievolutionary teaching that boiled the Bolsheviks down to murderous animals.

In his own sermons, on the weekly televised Old Time Gospel Hour and elsewhere, Jerry Falwell stuck to themes that he had raised in the initial issue of the Moral Majority Capitol Report sent to a choice list of fundamentalist preachers, thanks to the goodwill of John R. Rice. There, in August 1979, he had lamented that "the schools are steeped in humanistic philosophy, guided by atheistic and vulgar textbooks, rotten with drugs, sexual permissiveness and lack of discipline." Evolution was never his main theme. But its undertones reverberated widely. ${ }^{109} \mathrm{On}$ abortion, he charged on the OTGH, young people had become "amoral." They want to "live like animals" and have sex with "no consequences." In contrast, Bible-believing Christians "reject any form of evolutionary 
teaching." 110 In his sermon on communism, Falwell explained that it was essentially "godless atheism," which "represents and approaches humanity as nothing more than animal creatures." The "real controversy" was between "Christ and Satan," which logically linked the Great Deceiver with communism and evolution both. ${ }^{111}$ Preaching on "sexual promiscuity" - which for Falwell included adultery, premarital sex, and homosexuality - he contended that the story of God's creation of Adam was essential for maintaining a true Christian and therefore moral perspective. Life didn't "just happen," Falwell said. "We did not evolve from some lower form of life." Believing in God as creator and rejecting evolution would strengthen Christians' ability to live a sexually clean life. As he put it, "You don't need to live like an animal." Speaking to the Christian Life Commission's "Strengthening Families Seminar" in 1982, Falwell cited Francis Schaeffer on the dangers of secular humanism and explained that "I personally believe that evolution is the cardinal doctrine of secular humanism." Thus, whenever Falwell spoke of the evils of humanismwhich he often did-he was implicitly taking aim at evolution. ${ }^{112}$

Like many fundamentalists before him, Falwell possessed a deep conviction that the Christian masses of America had been lulled into complacency and needed to be shocked into recognizing the twin dangers of evolutionary humanism and communism. He expressed this in a variety of ways, including the notion that they needed to get a case of "spiritual heartburn" to awaken them. In frustration, and using another well-worn metaphor, Falwell wrote, "I don't know what it takes to dynamite Christians out of their spiritual sleep." 113 Preaching was Falwell's strength, but he also got into the book-writing business. Beyond the 1.5 million who watched the OTGH in the early 1980s-who made it the most popular syndicated Christian program in the US-a potentially bigger audience was awakened in August 1980, just months before the nation elected Ronald Reagan the nation's fortieth president, when they read Falwell's Listen, America! ${ }^{114}$

Having made headlines with the launching of the Moral Majority the previous year, Falwell wrote Listen to bid for public respectability as a "serious" author. Published by Doubleday and then brought out as a Bantam paperback to the tune of 150,000 copies in 1981, the book sported a fifty-title bibliography. As a reporter for the New York Times discovered while scouting out the political scene in Oklahoma City shortly before 
the 1980 elections, Falwell's book was prominently featured in local bookstores. While Oklahomans had gone Republican in the 1976 election, Ford's margin over Carter had been slim, and Falwell hoped to help Republicans' chances. When he spoke in Tulsa at a missions conference in the summer of 1980, he boosted the campaign of State Senator Don Nickles, who would ride in on Reagan's coattails that fall and serve as US senator from Oklahoma until 2005. ${ }^{115}$

Packing his 234-page book with historical specifics, Falwell also hedged his bets, providing a two-page prologue that began right inside the front cover and ended inside the back one. To draw in readers, Falwell retold the story of "Jack and the Beanstalk" and likened America to the sleeping giant, who had been lulled to sleep by indulging in the "good life." A veritable army of Jacks, consisting of "the abortionists, the homosexuals, the pornographers, secular humanists, and Marxists," were making off with the giant's "goods." But all was not lost. Signs that the giant was awakening included the virtual defeat of the ERA, the passage of the Hyde Amendment, and support for balanced-treatment bills in state legislatures. A slightly longer three-page précis of the book-under the heading "Seven Principles That Made America Great"-was confusingly sandwiched in between the last chapter and the end of the prologue. It also highlighted evolution, lamenting under the principle of "God-centered education" that creationism was no longer taught.

For those who persevered and tackled the meat of the book, there was a fair chance they would encounter the issue of evolution and its immoral communist connections. In "Understanding Our Times," which spelled out the wide extent of humanist-inspired sinfulness, Falwell pointed to humanism and "naturalism," the latter term referring to the view of "man as a kind of biological machine." From this standpoint, Falwell explained, "sexual immorality is just another bodily function, as is eating and drinking." ${ }^{116}$ Either because of sloppy editing or a desire to reinforce the point, Falwell repeated this paragraph almost word for word in a later chapter. It was followed by a section profiling "sexual anarchy" on the nation's campuses, language that Falwell also used in the pages of the Fundamentalist Journal. That phrase nicely captured the political and sexual implications of evolution. Finally, on the first page of the chapter on "The Threat of Communism," Falwell informed readers, accurately, that the Marxist 
conception of morality denied absolutes and depended, quoting Lenin, on the needs of the class struggle. Moving from social to biological evolution, Falwell indicated (quoting an unnamed source) that another "scientific law of communism" was that "man is simply matter in motion." In his own words, Falwell explained that Marx taught the idea that "man was an evolutionary animal and as such had no eternal life." ${ }^{117}$ Falwell was no Fred Schwarz, but he grasped the philosophical essentials that linked Darwin and Marx.

The same can be said of another man who learned from Fred Schwarz and became president of the United States: Ronald Reagan. Even before his election in November 1980 with the help of Falwell's Moral Majority, Reagan had given signs that he would be friendly to creationist politics. To be sure, he had some fences to mend with Jerry Falwell. In 1978, the former California governor had opposed Proposition 6, which banned gays and lesbians from working in the state's public schools. He was divorced and not much of a churchgoer. But Reagan did count himself a born-again Christian. And he was an inveterate anticommunist, having been schooled by his activism in the Screen Actors Guild, his employment as a company spokesman with General Electric, and his exposure to Fred Schwarz, the Harding College program, and similar ventures. ${ }^{118}$ In August 1980, Reagan spoke at the Religious Roundtable National Affairs Briefing in Dallas to some fifteen thousand evangelicals. He lamented the moral decline of America. The schools, he told the crowd, "have tried to educate without ethics." The result, Reagan said, was a rise in "crime rates, drug abuse, child abuse, and human suffering." When a reporter asked Reagan about evolution, the candidate responded, "I have a great many questions about it. It is a theory, a scientific theory only. . . I think recent discoveries down through the years pointed [to] great flaws in it." "Creationist theory," Reagan added, ought to be taught alongside evolution in the public schools. ${ }^{119}$ Reagan's comments alarmed pro-evolutionists and even appeared to be a "gaffe" that might sink his election chances. But the ICR happily headlined the candidate's comments in Acts \& Facts, bolding the quotations from Reagan about evolution for emphasis and fixing on his comments about "ethics." 120

Once Reagan took office, he rarely said a word about biological evolution. But Reagan's anticommunism and social antievolutionism combined 
in an intriguing way in one of his most controversial addresses: the "evil empire" speech. Remembered mainly for its militant characterization of the Soviet Union, Reagan's March 8, 1983, speech to the National Association of Evangelicals began, after the obligatory folksy humor, with an attack on young women's reproductive rights. In response to growing access to birth control for teenagers at federally funded clinics, the Reagan administration had proposed a new rule requiring parental notification. ${ }^{121}$ For Reagan, like John R. Rice in the 1940s, the growing use of birth control was a sign of spreading sexual sin. The president noted with scorn that the adjective "sexually active" had replaced the more presumably accurate "promiscuous." Reagan then proceeded to decry abortion as an attack on the sacredness of human life. Only after outlining these signs of America's moral decline did he arrive at his "final point," an indictment of the morality of Soviet leaders. ${ }^{122}$

To build his case that the Soviet Union was "the focus of evil in the modern world," Reagan pointed to the Marxist conception of morality, as he had done in his very first presidential press conference in early 1981. At that time, in response to a question about Soviet foreign policy aims and the possibility for détente, Reagan had replied that Soviet leaders had been perfectly open about their aims for world revolution. Their moral code was based on "whatever will further their cause." As opposed to Americans who followed a higher morality, Reagan explained, the Soviets "reserve unto themselves the right to commit any crime, to lie, to cheat," as long as it serves their ultimate goal. Now, two years later, he took the same tack, this time citing a 1920 Lenin speech. As Reagan paraphrased the Bolshevik leader, the Soviets "repudiate all morality that proceeds from supernatural ideas—-that's their name for religion—or ideas that are outside class conceptions. Morality is entirely subordinate to the interests of class war. And everything is moral that is necessary for the annihilation of the old, exploiting social order and for uniting the proletariat." 123

Delivered after a decade of détente and "peaceful coexistence," Reagan's speech caused a storm of protest. ${ }^{124}$ But his summary of Lenin's argument was correct. The president implicitly targeted the Marxist materialist and evolutionary conception of morals. Moral standards change, both over time and depending on which class interest they serve. In all of this, Reagan demonstrated himself to be a worthy student of Fred Schwarz. He even quoted, without mentioning names, Pat Boone's 
comment at Schwarz's Los Angeles rally about letting his little girls die in a nuclear holocaust rather than live under communism. ${ }^{125}$ Reagan had arrived at the philosophical heart of the matter.

While Baptists of various kinds-Bible Baptist Fellowship, Southern Baptist Convention, and independent-dominated the Moral Majority executive board that helped land Ronald Reagan in the White House, the one non-Baptist, D. James Kennedy (1930-2007), was no bit player. ${ }^{126}$ Even more than Jerry Falwell, Kennedy established a Red Dynamite political legacy that still lives today. Born in Augusta, Georgia, and raised in Chicago and then Tampa, Florida, young Jim Kennedy was a talented clarinet player who won a music scholarship to the University of Tampa. But he soon dropped out to work as an Arthur Murray dance instructor and engage, by his own account, in all manner of sin. It was a seemingly chance encounter with radio preaching, emanating from his alarm clock, that led Kennedy to God. In 1956, he entered Columbia Theological Seminary in suburban Atlanta, affiliated with the conservative Southern Presbyterian Church in the United States (PCUS), formerly the Presbyterian Church in the Confederate States of America. ${ }^{127}$ Columbia had been the site of fierce battles over evolution in the late nineteenth century. Their primary casualty was Professor James Woodrow, a theistic evolutionist fired for his heretical views in $1888 .{ }^{128}$ Columbia had also been home to Professor James Henry Thornwell (1812-1862), a famed Christian apologist for slavery and an influential exponent of the thesis that the Civil War pitted a devout Christian South against a heretical, atheistic North. ${ }^{129}$ Kennedy would absorb elements of both these intellectual traditions as he went forward into the world as an ordained Presbyterian minister in 1959.

Taking the helm at tiny Coral Ridge Presbyterian in Fort Lauderdale, Florida, the following year, Kennedy built it into a mega-church over the next two decades, attaining a membership of five thousand by 1976 . In 1978, Kennedy took his church out of the PCUS and into the newly formed and even more conservative Presbyterian Church in America (PCA). Like Jerry Falwell, Kennedy reached a growing body of congregants by radio and television and added a school and seminary to his church. Unlike the Lynchburg preacher, Kennedy earned his doctorate-from New York University in religious education. He was an effective teacher, best known 
for his methodical, door-to-door patient explanations, which he trademarked in a popular handbook, Evangelism Explosion. ${ }^{130} \mathrm{He}$ also relied on the force of his personality. Once speaking at a creationist conference with Kennedy, the ICR's John Morris heard a comment about Kennedy that rang true: "That's the only person I've ever seen who can scream in body language." 131 Starting in 1978, millions of viewers watched Kennedy weekly on the Coral Ridge Hour, as the pastor expressed that body language with a rich, baritone voice, boyish good looks, his signature "royal blue gown," and an authoritative professorial air. ${ }^{132}$

Kennedy conveyed the same basic message about moral decline that fellow Moral Majority leaders LaHaye and Falwell were spreading, but with a Reformed "Reconstructionist" flavor. In Why I Believe (1980), Kennedy armed his followers against doubts that Satan planted in the minds of those who had failed to put in the "intellectual effort" to ground their Christian faith securely in knowledge. On the topic of evolution-on which Kennedy repeatedly preached over the decadesuch knowledge included the laws of probability, which meant that a human cell could not have evolved "by chance." There was also the compelling political and historical knowledge that evolution, as Dan Gilbert had explained, was the root of every "ism." Nazism drew upon the "evolutionary platitudes" of Nietzsche. In a unique twist on the Marx-Darwin legend, Kennedy told readers not that Marx had offered to dedicate Das Kapital to Darwin, but that it was "well known" that Marx had asked Darwin to write the book's introduction. However badly Kennedy had mangled his facts, his concluding thought would have resonated with many readers: the same people pushing the "Communist conspiracy" were also pushing "an evolutionary, imperialistic, naturalistic view of life," which, in a poetic phrase, would "crowd the Creator right out of the cosmos." 133 Summing up the godly alternative to that worldview, Kennedy provided a clue to his emerging Reconstructionist theology. The system of God-given ethics, wrote Kennedy, using the distinctive language of R. J. Rushdoony, was "theonomous," or based on God law. ${ }^{134}$

Kennedy's next book was more forthright on this point, starting with its title: Reconstruction: Biblical Guidelines for a Nation in Peril (1982). ${ }^{135}$ Focusing his fire on the "morally bankrupt leadership" of the country, Kennedy lamented the "evils" that this had imposed on the American 
people: liberal theology, relativistic ethics, socialist economics, statism, corruption, and cultural immorality. The task before us, Kennedy believed, was to "reconstruct America with the Biblical guidelines which God has given us." 136 Starting with the subject of ethics, which he considered the "seed-plot" of his plan, Kennedy surveyed the variety of non-godly ethical systems. Since the goal, in Jeremy Bentham's famous formulation, was the "greatest good for the greatest number," anything done to perpetuate the human "species" could be justified, even at the expense of those with "bad genes." The Nazis took this logic to its natural conclusion. Then the Communists applied it, killing tens of millions in the name of a promised earthly "paradise." 137

Kennedy's Reconstructionist-tinged discussion of education also led him to the evolutionary-communist nexus. He asked, What is the purpose of education? Was it to produce good citizens? To enable self-realization? To graduate young people who were "well adjusted" to their environment? None of these was adequate. Citing Calvin, Kennedy explained that the purpose of education was, instead, to "know God and glorify Him as God." Citing R.J. Rushdoony, and taking special aim at the "adjustment" theory, Kennedy pointed out the false "naturalistic assumption" (or presupposition) underlying secular education. What if the environment to which students were adjusting was immoral, such as in Communist Russia where the naturalistic atheistic rulers viewed "men as little more than complicated mice" who could be killed "by the tens of millions" without consequences? During his own college education, Kennedy recalled that a professor had told him that "matter in motion" was all that existed. If so, then the products of American secular education would be well adjusted to the "natural" environment but "maladjusted" to God. ${ }^{138}$

Even Kennedy's pro-capitalist, antisocialist discussion of economics was based on a rejection of evolution. Referring to the biblical basis in Genesis for Rushdoony's "Dominionism," Kennedy reminded readers that as human beings created in the image of God, they were God's "vice-regents" who had "dominion" over the earth. As "steward" over the things we possess, thanks to God's creation, we are obligated to use that wealth in a manner consistent with biblical teachings, which favor "capitalism" (evident by virtue of the Eighth Commandment-"Thou shalt not steal"). Kennedy contrasted capitalism with socialism, which he defined as "government ownership." Despite claims that Nazi Germany 
was opposed to socialistic Russia, Kennedy wrote, they were just "two forms of the socialistic concept." His exposition of the biblical basis of free enterprise drew on familiar arguments developed by fellow conservative Presbyterian Carl McIntire, Baptist John R. Rice, and others during the early Cold War years. ${ }^{139}$

What distinguished Kennedy's Christian pro-capitalism from that of John R. Rice was his Reformed slant. In developing the pro-free enterprise argument, Kennedy leaned heavily on John Calvin. The great Geneva theologian was the "prime mover" of capitalism, who freed money from the "bondage" imposed on it by the medieval Catholic Church. The source of Kennedy's information on Calvin was mentioned only once in the text, but it was likely significant. This source was historian C. Gregg Singer (1910-1999), a PhD from the University of Pennsylvania and an elder in the Southern Presbyterian Church (PCUS). Unlike his fellow aspiring historian and contemporary R. J. Rushdoony, Singer had a successful academic career, teaching history in a string of Christian colleges and publishing books that reflected his conservative Reformed perspective. Most influential was A Theological Interpretation of American History (1964; rev. 1981 and 1994), which surveyed the impact of theology on the main currents of American history from the Puritans to the Moral Majority. By the mid-1980s, Singer's book was required reading at Liberty University. ${ }^{140}$ Baptist and Reformed theological strains intertwined on the Liberty campus to convey the twin dangers of evolution and communism.

By the late 1980s, thanks to the combined efforts of Kennedy, Falwell, LaHaye, Rushdoony, Reagan, and others, the significance of the evolution question had become clearer for millions of evangelical Christians. The cross-fertilization between the work of scientific creationists and fundamentalist activists bore plentiful fruit. Henry Morris had now spent four decades writing about the evils of evolution. In 1989, Baker House published Morris's crowning achievement, The Long War against God. The book contained more than three hundred footnoted pages. But it was accessibly written. And it conveniently summed up in one volume the lessons that Morris wanted the nation's Christians to learn before it was too late.

Even as the ICR was gaining momentum in the broader stream of conservative Christianity, the challenges of making evolution relevant emerged 
in the book's introduction penned by Rev. David Jeremiah. Succeeding Tim LaHaye at Scott Memorial Baptist in 1981, Jeremiah served as president of Christian Heritage College and preached on the radio every week through his Turning Point Ministries. When he first met Henry Morris, Jeremiah was not sure Morris was on the right track in placing evolution at the center of the ICR's ministry. "I wondered if perhaps his perspective had been clouded by a narrow focus of study over the years," Jeremiah wrote. One can imagine Jeremiah making this way through a technical article in Acts \& Facts and scratching his head in puzzlement. But having learned the full scope of evolution's consequences from Morris, Jeremiah had seen the light. "I am now convinced," he wrote, "that all significant problems of society are the children of an ignorant or indifferent attitude toward creationism." Even though the ordinary person "neither knows nor cares much about the error of evolution," Jeremiah acknowledged, it affects his life profoundly. The evil fruits of evolution included "pornography, adultery, divorce, homosexuality, premarital sex, [and] the destruction of the nuclear family." Jeremiah also embraced Morris's conclusion, reflected in his book's title, that the true origin of evolutionary thinking went back to ancient times when Satan first uttered his "big lie about the universe." 141

In Long War, after documenting the undeniable impact of evolution on a wide spectrum of academic theory, Morris proceeded to deal with the social and political practice that had resulted, what he called "Political Evolutionism—Right and Left." Morris's chapter title promised political evenhandedness, and his approach did yield some valuable insights. In tracing conservative social Darwinism, of the Carnegie and Rockefeller type, for instance, Morris noted that this tradition persisted in the world of latter-twentieth-century conservatives who did not identify strongly enough, in his opinion, with evangelical Christianity. He correctly observed that Robert Welch of the John Birch Society, a nominal Christian, was a "strong evolutionist." He bemoaned the fact that conservative evangelical hopes in Ronald Reagan's administration had been edged out by "economic measures designed to restore a greater degree of Darwinist laissez-faire capitalism." ${ }^{142}$ These observations supported Morris's contention that his opposition to evolution was not political, since both leftand right-wingers were, in practice, evolutionists. 
The same seeming impartiality appears in Morris's substantial sections on Hitler and communism. Citing and quoting from scholarship that traced the impact of the ideas of Spencer, Darwin, Nietzsche, and Haeckel on Hitler, Morris made the case that the Führer was the "ultimate fruit of the evolutionary tree." Even the title of Mein Kampf, "my struggle," displayed Hitler's evolutionary bent, his debt to the "DarwinSpencer-Haeckel emphasis" on the "struggle for existence." To back his claims about left-wing evolutionism, Morris quoted amply from scholarship showing the support Darwin received from Marx and Engels. He pointed to the Marxist aspects of Gould and Eldredge's work on punctuated equilibrium and their opposition to Wilson's sociobiology. He trotted out Marxist historian Robert Young on the inevitably political nature of science. He even quoted from a 1980 analysis of creationism by Socialist Workers Party (SWP) leader Cliff Connor published in the Militant newspaper that accurately reported, "Defending Darwin is nothing new for socialists." Like their political predecessors in the era of the Scopes trial, the SWP continued to argue that the "cultural" issues of social and biological evolution were critical for the working-class fight for power. ${ }^{143}$

Despite his seemingly undifferentiated hostility to evolutionists of the Right and Left, a closer examination brings Morris's own politics more sharply into focus. In an attempt to distance his own worldview from Hitler's, Morris refers to "certain attempts to depict Hitler as a rightwinger, or even as a Christian." Morris's response: "Even though he was an anti-Communist (except when it suited his devious thinking to unite with Russia in the pact that precipitated World War II!), Hitler was certainly not a Christian, in any sense whatever." ${ }^{144}$ Yet Morris offers no additional information to his readers about Hitler's anticommunism-an essential ingredient in Nazi ideology. In effect, Morris admits that Hitler was "one of us" in his militant anti-communism but fails to explore the damaging implications. It was precisely that common ground that had led William Bell Riley—who had chosen Morris as his heir apparent at Northwestern-to praise Hitler and led others to sympathize more quietly with him. Though Riley was long gone, Morris's ties to Northwestern lived on, as the ICR regularly held summer institutes on that St. Paul, Minnesota, campus. ${ }^{145}$ 
Morris's political perspective comes out more clearly in his coverage of left-wing evolutionism. Modern evolutionists may try to dismiss early cases of right-wing social Darwinism as "irrelevant today," notes Morris. But they cannot deny that socialism and communism represent a "current problem in every sense of the word!" Governments promoting some form of Marxist ideology "reign over most of the world's nations"; Marxist theory is taught in colleges as "the wave of the future"; even liberals in the Democratic Party promote "Marxist policies." If one compares the human toll of communism and Nazism, the latter pales before the former. The number of people slaughtered in the "class struggle" exceed "by a factor of ten or more" those who died from Hitler's "genocidal aggressions." Hitler was bad, but the communists were at least ten times worse.

Not that Morris's comparative judgment on Marxist and Nazi evolutionism was based on a mathematical calculation. The heart of his argument could be found, instead, in a chapter called the "The Dark Nursery of Darwinism." Here Morris's readers learned once again about Darwin's predecessors and their participation in a shadowy worldwide political conspiracy linked to the French Revolution. The plotters included geologist Charles Lyell, Erasmus Darwin, who anticipated his grandson's evolutionary ideas, and Jean-Baptiste Lamarck. Morris reviewed the attraction of Lamarckism for Soviet science, restated once again the demonstrably false fact that Marx wanted to dedicate Capital to Darwin, and reminded readers about Stephen Jay Gould's Marxist ties. The main point was that Marx and Lamarck were somehow linked in a worldwide secret plot. ${ }^{146}$

To the charges of mass murder and secret plotting, Morris now added the whopper that gave his book its distinctive punch: the key player behind the revival of evolutionary ideas during the nineteenth century was Satan. He worked directly through two key figures, who represented both biological and social evolution: Alfred Russel Wallace and Karl Marx. As Morris tells his readers, Wallace was a religious skeptic who "was long enamored of socialism, Marxism, and even anarchism." He also developed a fascination with spiritualism based on a pantheistic notion of disembodied spirits in nature. But Wallace is best known as the codiscoverer of the idea of natural selection, which came to him while enduring a "rather severe attack of intermittent fever" in the Molucca islands 
of Malaysia. By Wallace's account, the idea of incorporating the population theories of Thomas Malthus-a key piece of the natural selection concept- - suddenly flashed upon me." For Wallace, this inspiration must have come from the natural spirit world. But the only spirits Morris recognized were the demons mentioned in the Bible. From this perspective, Morris concludes, "it is not naïve fundamentalism but essential realism to recognize that Satan ... would somehow be very directly involved in this watershed development of 1858-59." 147

Whereas Wallace appears in Morris's account as an unwitting tool of Satan, Karl Marx was an active accomplice. Here Morris relied on a book by Richard Wurmbrand, the former imprisoned Romanian pastor and anticommunist confederate of Billy James Hargis. In Marx and Satan (1986), Wurmbrand probed the writings of the young Karl Marx to argue that he not only became an atheist after his years in a Lutheran high school but "became a Satan worshipper who regularly participated in occult practices and habits." Evidence from Marx's early work included the drama Oulanem (in Wurmbrand's estimation, a satanically inspired anagram of Emmanuel, a biblical name of Jesus) and the poem "The Player," both written during Marx's high school years. Morris quotes a stanza from the latter, including the lines, "See this sword? I The prince of darkness / Sold it to me." According to Morris, Wurmbrand explains that these lines reference "rites of initiation in the Satanist cult, in which an enchanted sword ensuring success in life is sold to the initiate for the price of a blood covenant with Satan for his soul in death." ${ }^{148}$ Marx thus appeared worse than Hitler not only in the number of his minions' victims, but because Marx, apparently unlike Hitler, was a practicing satanist.

Following the satanic trail backward through history, Morris arrived in ancient times, where he moved through ancient evolutionary-inspired pantheism to the early Greek materialists and finally to Babel. Morris had trod this territory since his collegiate poem on King Nimrod in the 1940s. But Long War was his definitive treatment. He summed up the results of his historical investigation for readers: "This means, finally, that the very first evolutionist was not Charles Darwin or Lucretius or Thales or Nimrod, but Satan himself!" Morris seemed less than 100 percent certain on his sub-points. On the possible connection between Marx's satanism and the millions murdered by Communists in the twentieth century, Morris 
ventured that "one cannot help sensing some kind of occult cause-andeffect relation." But the ICR's publicity for The Long War against God was unequivocal. The cover story on the book in Acts \& Facts noted that while a satanic origin for evolutionism might be "ridiculed" by some, Henry Morris had demonstrated that it was "the only viable explanation." ${ }^{149}$ Creation science had proved Satan's role in evolution once and for all.

The ICR was flying high by the 1990s. One reason was the addition of a new Australian-born ICR staffer with a gift for gab. Born in 1951 into a fundamentalist family in Queensland, Australia, Ken Ham spent five years as a high school science teacher in the late 1970s. Under the impact of Henry Morris's writings, he became a full-time creationist activist. After spending a number of years in Australian creationist groups, specializing in providing educational materials to Queensland public schools-where teaching creationism along with evolution was legal until 1987-Ham came to the US in that year to offer his services to the ICR. An article in Acts \& Facts introduced Ham to the ICR faithful as "a skilled communicator, with a keen sense of humor and an entertaining accent." 150

Over the next seven years, Ham carved out a prominent place in the ICR landscape. He wrote a regular "Back to Genesis" column, adorned with cartoons, and taught "Back to Genesis" seminars to large crowds around the country. Ham's populist style contrasted sharply with Morris's more academic approach, but he was building on the older man's fruitistic foundation. In his first column for Acts \& Facts, Ham described evolution as Darwin's "repopularization" of "an ancient pagan belief" that today gave people license to practice "humanistic morality" and act as if there were no "absolutes." Evolutionary thinking explained the homosexual "lifestyle," abortion, and "easy divorce." A cartoon that accompanied a Ham column - which he used often in the coming decades-depicted a medieval battle between knights guarding rival castles, "Evolution" and "Christianity." The latter fired canons at balloons flying from the former, which included Divorce, Homosexuality, Pornography, Racism, and Abortion. In a sign of things to come, Ham's "fruits" pointedly did not include communism. ${ }^{151}$ 
The ICR reached an expanding popular audience in the 1980s and '90s through its Museum of Creation and Earth History. Founded in 1976 and originally housed on the Christian Heritage College campus in El Cajon, the museum attracted five thousand visitors by 1980. Its exhibits included the Origin of Mankind, the Origin of Birds, the Case for Creation, the Origin of Horses, and Creation: Life before Birth. In 1981, the ICR added a new display, Dinosaurs and Man in History, based on the soon-to-be discredited "Paluxy Man Tracks" near Glen Rose, Texas, which supposedly provided evidence that humans and dinosaurs lived at the same time. In 1986, the ICR opened new headquarters, including a new museum building, in nearby Santee, California. Perhaps thanks to the arrival of Ken Ham the next year, the ICR began to market a range of dinosaur-themed products designed for children. Visitors to the museum gift store could buy T-shirts, mugs, posters, and a Dinosaur ABC's Activity Book. ${ }^{152}$ Speaking at the new building's dedication ceremony, an aging John Whitcomb Jr., coauthor with Morris of The Genesis Flood, said that the completion of the new building could only have happened thanks to the power of an "infinite God," who could counter the influence of Satan and his "vast armies of evil spirits." 153

The final incarnation of the museum, in which rival creation and evolution trees displayed the good and evil fruits of Darwinism, took shape in 1992. The ICR moved the museum up a floor, where it occupied some four thousand square feet. Henry and John Morris wrote the bulk of the text for a new set of exhibits, relying heavily on The Long War against God. Visitors learned about the origins of evolutionary thinking in the ancient world, from Babel through the Greek materialists through "evolutionary" non-Christian world religions. To underline why Christians needed to understand the evolution issue, Morris devoted a panel to explaining why it was a "dangerous error" to ignore the question of origins. "The tree of evolution bears only corrupt fruits," the panel read. "Creationism bears good fruits." By 1997, five years after the renovation, some one hundred thousand people, from nearly every US state and at least twenty other countries, had visited the new museum. To a degree that Henry Morris and John C. Whitcomb Jr. could never have imagined, young-earth creationism had arrived. ${ }^{154}$

It was only the beginning. In 1994, Ken Ham struck off on his own, and in 2007 his organization, Answers in Genesis, opened a multimillion-dollar 
creation museum in Petersburg, Kentucky, that put the Santee museum to shame. The fruits of evolution in the new facility's exhibits did not explicitly include Karl Marx or communism. In the new political context of the early twenty-first century, anticommunism did not carry the same weight as it did even in the early nineties, when the Soviet Union was crumbling. That did not mean, however, that Red Dynamite had forever faded. A whole cast of characters, both old and new, kept the tradition alive into the Trump era. 